\title{
The Impact of Macro Environmental Factors on Essential Oils of Oliveria decumbens Vent. from Different Regions of Iran
}

\author{
Seyyed Mohammad Hosein Ale Omrani Nejad ${ }^{1}$, Hassanali Naghdi Badi ${ }^{2,{ }^{*}}$, Ali Mehrafarin ${ }^{2}$, Vahid \\ Abdossi $^{1}$ and Farahnaz Khalighi-Sigaroodi ${ }^{2}$ \\ ${ }^{1}$ Department of Horticulture, Science and Research Branch, Islamic Azad University, Tehran, Iran \\ ${ }^{2}$ Medicinal Plants Research Center, Institute of Medicinal Plants, ACECR, Karaj, Iran \\ "Corresponding author: Medicinal Plants Research Center, Institute of Medicinal Plants, ACECR, P.O. Box: 31375/1369, Karaj, Iran. Tel: +98-2634764010, Fax: +98-2634764021, \\ Email: naghdibadi@yahoo.com
}

Received 2017 August 05; Revised 2018 December 18; Accepted 2018 January 22.

\begin{abstract}
Background: Environmental factors may affect qualitative and quantitative properties of essential oil in medicinal plants. Objectives: The aim of the present study was to determine the effect of macro environmental factors on essential oils content and composition of Iranian populations of Oliveria decumbens.

Methods: The aerial parts of 25 wild populations of Oliveria decumbens Vent. were collected from various natural habitats in the southwest of Iran. The essential oil of samples was analyzed by gas chromatography (GC) and gas chromatography-mass spectroscopy (GC-MS). Therefore, macro environmental factors were determined by the PCA method. The correlations between the factors were calculated based on the Pearson correlation coefficient.

Results: The major compounds of essential oils were thymol, carvacrol, p-cymene, and y-terpinene, respectively, with an average of $28.77 \%, 25.31 \%, 14.02 \%$, and $8.12 \%$. The results showed that the altitude, mean evaporative per month (MEM) and Mean Day Temperature (MDT) were effective macro environmental factors on essential oil, thymol, and carvacrol content.

Conclusions: The highest content of essential oil, thymol, and carvacrol was related to warm and semi-humid regions.
\end{abstract}

Keywords: Oliveria decumbens Vent., Essential Oil, Environmental Factors, Thymol, Population

\section{Background}

Oliveria decumbens Vent., a member of the Umbelliferae family, is a shrub commonly found in the south-east of Iran. In traditional medicine, its aerial part was used for treating indigestion, diarrhea, abdominal pains, and fever (1). According to recent studies, it can be used as an antibacterial (2), antifungal (3), antioxidant (4), and antimicrobial agent (1). These properties are influenced by quantity and quality of their secondary metabolites, which are usually produced under the influence of special environmental and climatic conditions. Therefore, the identification of the best environmental and climatic conditions is necessary.

A study on Thymus vulgaris showed that environmental conditions influenced essential oil composition (5). The study on chemical composition of essential oils and methanolic extracts of Thymus mastichina populations indicated that the total phenol contents of the methanolic extracts varied between 2.90 and $9.15 \mathrm{mg}$ GAE/g extract. Also, the oil yields varied between 2.27 and $6.48 \mathrm{~mL} / 100 \mathrm{~g}$
DM. This difference seems to be related to the different environmental conditions (6). The investigation on Lavandula $\times$ intermedia from ten regions of Zagros regions of Iran showed significant differences for essential oil content and composition due to differences in environmental conditions (7). In another study, the essential oil content of Thymus pubescens had a significant positive relationship with soil $\mathrm{pH}$ and also a significant negative relationship with altitude (7). The major environmental factors had a significant effect on essential oil of Verbascum songaricum. It's essential oil content was increased under semiarid cold climate, uplands, higher precipitation, relatively light texture, and fertile soil (8).

\section{Objectives}

Climate variation and altitude changes affect essential oil biosynthesis and accumulation in medicinal herbs. Therefore, evaluation of the effects of different climatic conditions on plants is important. Since, there is no published and comprehensive research related to the effect of

Copyright (c) 2019, Jundishapur Journal of Natural Pharmaceutical Products. This is an open-access article distributed under the terms of the Creative Commons Attribution-NonCommercial 4.0 International License (http://creativecommons.org/licenses/by-nc/4.0/) which permits copy and redistribute the material just in noncommercial usages, provided the original work is properly cited. 
different climatic conditions on 0 . decumbens, the present study was carried out to explore the effects of macro environmental factors on phytochemical changes of 0 . decumbens.

\section{Methods}

\subsection{Geographical Characteristics of Habitats}

According to a pervious study, natural habitats of Oliveria decumbents were identified (9). The locations characteristics are shown in Table 1.

\subsection{Metrological Characteristics of Habitats}

The climatic characteristics were determined using the nearest meteorological stations. The type of climate classification of each region was indicated according to the coefficient of temperance method (Temoenatenus Index)(Table 1).

\subsection{Soil Characteristics of Habitats}

The soil samples were taken from the root depth of plants and their physicochemical properties were determined (Table 2). The total nitrogen $(\mathrm{N})$, phosphorus $(\mathrm{P})$, and potassium $(\mathrm{K})$ were determined using the Kjeldahl procedure, Olsen method, and a flame photometer, respectively. The total neutralizing value (TNV \%) by neutralization with $\mathrm{HCl}$ and the organic matter (OM\%) by titration method were measured (10).

\subsection{Plant Collection}

In all habitats, area 1 parts of 0 . decumbens in the flowering stage were taken by a random-systematic method along with the located transects. This plant was identified and recorded by Seed Bank of Medicinal Plants Institute, ACECR (1364-MPISB). Four plants were collected from each transect between mid-June to mid-August, 2015. The samples were then dried in shaded areas at room temperature.

\subsection{Essential Oils Extraction}

The Essential Oil (EO) was obtained by hydrodistillation method for three hours, using Clevenger apparatus, according to the pharmacopoeia (11). Then, essential oil content (\%) was measured based on mass of essential oil ( $\mathrm{g}$ ) extracted from $50 \mathrm{~g}$ mass of dried aerial part $(\mathrm{g})$ using the following formula (12).

EO content $\%=\frac{\text { mass of EO obtain }(g)}{\text { mass of dry matter }(g)} \times 100$

\subsection{Gas Chromatography}

Analytical gas chromatography (GC) was performed using a Younglin Acme6000 gas chromatograph equipped with BP-5 column $30 \mathrm{~m}, 0.25 \mathrm{~mm}$ internal diameter, and $0.25 \mu \mathrm{m}$ film thickness. The column temperature program was set as follows: Oven temperature was held at $50^{\circ} \mathrm{C}$ for five minutes, from 50 to $240^{\circ} \mathrm{C}$ at a rate of $3^{\circ} \mathrm{C} / \mathrm{min}$ and to $300^{\circ} \mathrm{C}$ at a rate of $15^{\circ} \mathrm{C} / \mathrm{min}$ and held at this temperature for three minutes. Injection and detection temperature was $290^{\circ} \mathrm{C}$ and $300^{\circ} \mathrm{C}$, respectively. Helium was used as carrier gas with a linear velocity of $0.8 \mathrm{~mL} / \mathrm{min}$. All samples were diluted 1:100 by the N-Hexane solvent. One microliter of the diluted sample was injected manually in the split mode 1:25 (13).

\subsection{Gas Chromatography-Mass Spectroscopy}

The gas chromatography-mass spectroscopy (GC-MS) analyses were carried out with the Agilent 6890 system equipped with a Mass-Spectrometer Agilent 5973, as a detector and a BPX5 column ( $30 \mathrm{~m}, 0.25 \mathrm{~mm}$ internal diameter, and $0.25 \mu \mathrm{m}$ film thicknesses). The carrier gas was helium at a flow rate of $0.5 \mathrm{~mL} / \mathrm{min}$. The column temperature was held at $50^{\circ} \mathrm{C}$ for five minutes, and was gradually increased from 50 to $240^{\circ} \mathrm{C}$ with a rate of $3^{\circ} \mathrm{C} / \mathrm{min}$ and to $300^{\circ} \mathrm{C}$ with a rate of $15^{\circ} \mathrm{C} / \mathrm{min}$ and held at this temperature for three minutes. For detection, an electron ionization system was used with ionization energy of 70 Electron Volt. The injector and ionization source temperatures were 290 and $220^{\circ} \mathrm{C}$, respectively. One microliter of the sample was injected manually in the split mode 1:25 (13).

\subsection{Identification of Components}

The identification of the constituents was based on the comparison of the Kovats Indices $(\mathrm{KI})$ to n-alkanes $\left(\mathrm{C}_{8}-\mathrm{C}_{20}\right)$ and $\left(\mathrm{C}_{20}-\mathrm{C}_{40}\right)$ and mass spectra of authentic samples with library data of the GC-MS system and the literature data. Relative percentages of the identified compounds were obtained by the electronic integration of the FID peak areas.

\subsection{Statistical Analysis}

At first, the macro environmental factors were indicated by Principal Components Analysis (PCA), and correlations between these factors were calculated based on Pearson correlation coefficient by the Minitab software. As a result, the most important environmental factors and how they influenced the production of main essential oil component were identified. 


\begin{tabular}{|c|c|c|c|c|c|c|c|c|c|c|c|}
\hline Population No. & Province & Region & Latitude, $\mathrm{N}$ & Longitude, E & Altitude, $\mathbf{m}$ & MDT, ${ }^{\circ} \mathrm{C}$ & MDRH,\% & MPM, mm & MEM, mm & MSM, h & Climate \\
\hline 1 & Kermanshah & Soomar & $33^{\circ} 55^{\prime} 03.6 " \mathrm{~N}$ & $45^{\circ} 47^{\prime} 18.3^{\prime \prime} \mathrm{E}$ & 500 & 25.63 & 41 & 20.36 & 219 & 256 & Warm and dry \\
\hline 2 & Kermanshah & Qasr-e Shirin & $34^{\circ} 29^{\prime} 02.9^{\prime \prime} \mathrm{N}$ & $45^{\circ} 34^{\prime} 27.4^{\prime \prime E}$ & 345 & 24.59 & 40 & 30.25 & 218 & 259 & Warm and dry \\
\hline 3 & Kermanshah & SarpolZahab & $34^{\circ} 26^{\prime} 29.8^{\prime \prime} \mathrm{N}$ & $45^{\circ} 53^{\prime} 45.6^{\prime \prime} \mathrm{E}$ & 609 & 20.39 & 47 & 35.48 & 184 & 247 & Warm and dry \\
\hline 4 & Ilam & Bedreh & $33^{\circ} 16^{\prime} 27.5^{\prime \prime} \mathrm{N}$ & $47^{\circ} 09^{\prime} 23.33^{\prime E}$ & 896 & 22.58 & 43 & 17.41 & 132 & 242 & Warm and dry \\
\hline 6 & Ilam & Abdanan & $33^{\circ} 00^{\prime} 39.2^{\prime \prime} \mathrm{N}$ & $47^{\circ} 23^{\prime} 45.9^{\prime \prime} \mathrm{E}$ & 981 & 23.18 & 41 & 45.71 & 142 & 243 & Warm and dry \\
\hline 7 & Ilam & DarrehShahr & $33^{\circ} 04^{\prime} 40.0^{\prime \prime} \mathrm{N}$ & $47^{\circ} 30^{\prime} 07.0^{\prime \prime} \mathrm{E}$ & 655 & 22.58 & 41 & 34.25 & 141 & 241 & Warm and dry \\
\hline 8 & Khuzestan & Dezful & $32^{\circ} 21^{\prime} 56.6^{\prime \prime} \mathrm{N}$ & $47^{\circ} 57^{\prime} 59.0^{\prime \prime E}$ & 196 & 24.41 & 45 & 32.27 & 217 & 258 & Warm and semi-humid \\
\hline 9 & Khuzestan & Behbahan & $30^{\circ} 39^{1} 19.9^{\prime \prime} \mathrm{N}$ & $50^{\circ} 12^{\prime} 45.5^{\prime \prime} \mathrm{E}$ & 302 & 25.00 & 43 & 34.25 & 221 & 261 & Warm and semi-humid \\
\hline 10 & Khuzestan & Fedelak & $32^{\circ} 05^{\prime} 25.5^{\prime \prime} \mathrm{N}$ & $48^{\circ} 53^{2} 24.9^{\prime \prime E}$ & 236 & 27.88 & 44 & 25.06 & 209 & 256 & Warm and semi-humid \\
\hline 11 & Khuzestan & Perchestan & $32^{\circ} 03^{\prime} 13.6^{\prime \prime} \mathrm{N}$ & $48^{\circ} 55^{\prime} 13.7^{\prime \prime} \mathrm{E}$ & 165 & 27.88 & 44 & 25.06 & 209 & 256 & Warm and semi-humid \\
\hline 13 & Khuzestan & Masjedsoleyman & $32^{\circ} 00^{\prime} 56.0^{\prime \prime} \mathrm{N}$ & $49^{\circ} 1^{\prime} 37.5^{\prime \prime} \mathrm{E}$ & 275 & 25.73 & 39 & 35.50 & 218 & 255 & Warm and semi-humid \\
\hline 14 & Khuzestan & KuhZar & $32^{\circ} 05^{\prime} 14.3^{\prime \prime} \mathrm{N}$ & $48^{\circ} 57^{\prime 12.5^{\prime \prime} \mathrm{E}}$ & 109 & 27.07 & 43 & 22.79 & 207 & 257 & Warm and semi-humid \\
\hline 15 & Fars & Jahrom1 & $28^{\circ} 29^{\prime} 39.8^{\prime \prime} \mathrm{N}$ & $53^{\circ} 35^{\prime} 59.0^{\prime \prime} \mathrm{E}$ & 1104 & 23.42 & 47 & 19.40 & 219 & 279 & Warm and dry \\
\hline 16 & Fars & Jahrom 2 & $28^{\circ} 38^{\prime} 20.00^{\prime \prime} \mathrm{N}$ & $53^{\circ} 37^{\prime} 26.5^{\prime \prime E}$ & 1021 & 23.42 & 47 & 19.40 & 219 & 279 & Warm and dry \\
\hline 17 & Fars & Kazerun 1 & $29^{\circ} 36^{2} 24.2^{\prime \prime} \mathrm{N}$ & $51^{\circ} 34^{4} 32.7^{\prime \prime} \mathrm{E}$ & 874 & 24.38 & 42 & 29.46 & 255 & 267 & Warm and semi-humid \\
\hline 18 & Fars & kazerun 2 & $29^{\circ} 39^{\prime} 46.1^{\prime \prime} \mathrm{N}$ & $51^{\circ} 37^{\prime} 00.3^{\prime \prime} \mathrm{E}$ & 895 & 24.38 & 42 & 29.46 & 255 & 267 & Warm and semi-humid \\
\hline 19 & Fars & DoshmanZiari & $30^{\circ} 06^{\prime} 51.0^{\prime \prime} \mathrm{N}$ & $52^{\circ} 21^{\prime} 39.6^{\prime \prime E}$ & 1699 & 18.31 & 40 & 39.33 & 172 & 274 & Warm and semi-humid \\
\hline 20 & Fars & Nourabad & $30^{\circ} 04^{\prime} 49.6^{\prime} \mathrm{N}$ & $51^{\circ} 32^{\prime} 48.9^{\prime \prime} \mathrm{E}$ & 981 & 23.10 & 48 & 39.49 & 196 & 251 & Warm and semi-humid \\
\hline 21 & Fars & Ghaemiyeh & $29^{\circ} 51^{\prime} 45.6^{\prime \prime} \mathrm{N}$ & $51^{\circ} 34^{\prime} 56.7^{\prime \prime E}$ & 913 & 21.96 & 46 & 26.95 & 211 & 257 & Warm and semi-humid \\
\hline 22 & Lorestan & Kuhdasht & $33^{\circ} 33^{\prime} 06.6^{\prime \prime} \mathrm{N}$ & $47^{\circ} 32^{2} 34.8^{\prime \prime} \mathrm{E}$ & 1260 & 16.62 & 48 & 31.39 & 157 & 245 & Moderate and dry \\
\hline 23 & ChaharMahal VaBakhtiari & Lordegan & $31^{\circ} 31^{\prime 1} 14.8^{\prime \prime N}$ & $50^{\circ} 46^{\prime} 00.3^{\prime \prime E}$ & 1556 & 16.36 & 51 & 45.96 & 132 & 264 & Moderate and dry \\
\hline 24 & Bushehr & Borazjan & $29^{\circ} 21^{\prime} 20.2^{\prime \prime} \mathrm{N}$ & $51^{1} 16^{\prime} 56.8^{\prime \prime} \mathrm{E}$ & 146 & 26.66 & 43 & 19.02 & 246 & 257 & Warm and humid \\
\hline 25 & Hormozgan & Geno & $27^{\circ} 24^{\prime} 00.6^{\prime \prime N}$ & $56^{\circ} 14^{\prime} 05.9^{\prime \prime} \mathrm{E}$ & 653 & 27.32 & 53 & 14.51 & 259 & 270 & Warm and humid \\
\hline
\end{tabular}

Abbreviations: MDT, mean day temperature; MDRH, mean day relative humidity; MEM, mean evaporative per month; MPM, mean precipitation per month; MSM, mean sun hour per month.

\section{Results}

\subsection{Essential Oil Content and Composition}

The essential oil content in dry plant materials ranged between $2.25 \%$ and $6 \%$. The minimum and maximum content of essential oil of 0 . decumbens populations were obtained in kazerun 2 (2.25\%) and Fedelak (6\%) populations, respectively. The results obtained from GC and GC-MS analyses of the oils showed that the main compounds were thymol, carvacrol, p-cymene, and y-terpinene. The highest and the lowest values of thymol were observed in Kuhdasht (43.9\%) and Fedelak (0\%) populations, respectively. However, carvacrol content was differentially influenced by these two populations and its highest and lowest values were detected in Fedelak (35.98\%) and Kuhdasht (0\%) populations, respectively (Table 3 ).

\subsection{Important Environmental Factors Based on PCA}

Based on Principal Components Analysis (PCA), Latitude (N), Longitude (E), Altitude, Mean Day Temperature (MDT), mean evaporative per month of Class A pan evaporation (MEM), soil pH, and clay (\%) were major environmental factors that had significant effects on essential oil content and composition (Figure 1).

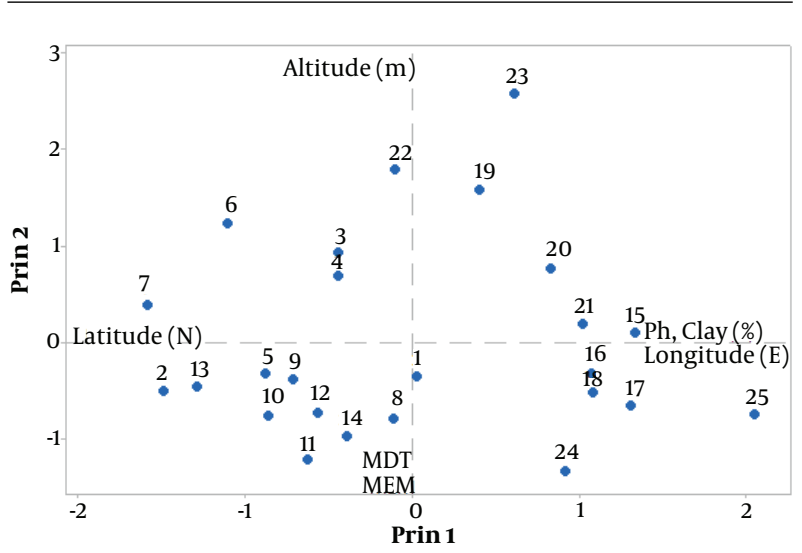

Figure 1. Principle Component Analysis (PCA) based on environmental parameters

\subsection{Correlation Between Environmental Factors and Essential Oil Composition}

The significant correlation between two variables were determined by P values greater than 0.05. Among the principal factors, only altitude showed a significant relationship with essential oil content, however, it was negative(Ta- 


\begin{tabular}{|c|c|c|c|c|c|c|c|c|c|c|}
\hline Population No & $\mathbf{P}(\mathbf{A v})$, ppm & K (Av.), ppm & $\mathrm{N}, \%$ & OM, \% & TNV, \% & $\mathrm{EC}, \mathrm{dS} / \mathrm{m}$ & pH & Sand, \% & Clay, \% & Silt, \% \\
\hline $\mathbf{1}$ & 3.4 & 141 & 0.17 & 0.41 & 41.1 & 2.1 & 8.2 & 33 & 30 & 37 \\
\hline 2 & 24 & 548 & 0.73 & 0.87 & 7.7 & 0.48 & 6.9 & 22 & 33 & 45 \\
\hline 3 & 9.7 & 280 & 0.15 & 1.3 & 48 & 0.52 & 7.3 & 25 & 30 & 45 \\
\hline 5 & 14.3 & 435 & 0.3 & 1.3 & 18 & 0.6 & 7.28 & 25.4 & 38.7 & 35.9 \\
\hline 6 & 12.2 & 324 & 0.21 & 0.21 & 10 & 0.59 & 7 & 20.3 & 39.7 & 40 \\
\hline 7 & 27 & 650 & 0.84 & 1.6 & 8 & 0.5 & 7.1 & 17 & 35 & 48 \\
\hline 8 & 11 & 107 & 0.74 & 1.12 & 11 & 5.27 & 7.1 & 58.16 & 13.48 & 28.36 \\
\hline 9 & 2 & 231 & 0.27 & 1.1 & 8 & 0.43 & 6.2 & 3 & 47 & 50 \\
\hline 10 & 7 & 106 & 0.4 & 0.61 & 8.3 & 0.92 & 6.8 & 5 & 43.5 & 51.5 \\
\hline 11 & 9 & 342 & 0.78 & 2.3 & 9 & 0.63 & 7.1 & 30.2 & 31 & 37.8 \\
\hline 12 & 11 & 112 & 0.41 & 0.84 & 7 & 1.4 & 6.9 & 37.4 & 20 & 42.6 \\
\hline 13 & 5 & 320 & 0.25 & 1.11 & 6 & 0.21 & 5.95 & 5 & 49 & 46 \\
\hline 14 & 8.4 & 121 & 0.38 & 0.73 & 8 & 0.86 & 6.9 & 41.9 & 17.2 & 40.9 \\
\hline 15 & 6.8 & 345 & 0.42 & 0.2 & 21.3 & 0.16 & 7.7 & 54.1 & 10.6 & 35.3 \\
\hline 16 & 6 & 261 & 0.62 & 1.7 & 31 & 1.78 & 7.8 & 19 & 9 & 72 \\
\hline 17 & 3 & 374 & 0.48 & 2.5 & 34 & 5.13 & 8.9 & 46.7 & 20.6 & 32.7 \\
\hline 18 & 6 & 275 & 0.57 & 0.35 & 32 & 3.78 & 7.9 & 52 & 10.8 & 37.2 \\
\hline 19 & 5.6 & 311 & 0.53 & 0.8 & 37 & 0.05 & 7.8 & 8.7 & 51.3 & 40 \\
\hline 20 & 6.1 & 342 & 0.46 & 0.53 & 42 & 0.1 & 7.9 & 51.5 & 11.8 & 36.7 \\
\hline 22 & 6.107 & 215 & 0.11 & 0.34 & 9 & 0.48 & 7.3 & 40.3 & 30.5 & 29.2 \\
\hline 23 & 8.8 & 288 & 0.102 & 0.89 & 30.75 & 0.222 & 7.95 & 24.13 & 31.2 & 44.67 \\
\hline 24 & 6.6 & 135 & 0.91 & 0.43 & 59 & 4.9 & 7.9 & 54.7 & 12.6 & 32.7 \\
\hline 25 & 5 & 175 & 0.21 & 1.51 & 37 & 0.52 & 8.32 & 61 & 7 & 32 \\
\hline
\end{tabular}

Abbreviations: EC, electrical conductivity; K, potassium; N, total nitrogen; OM, organic matter; P, phosphorus; pH, potential of hydrogen; TNV\%, total neutralizing value.

ble 4). Therefore, essential oil content of 0 . decumbens increased in some regions by decreasing the elevation. Correlation analysis showed that thymol content had not significant correlation with selected environmental factors. In contrast, significant correlations between carvacrol content with MDT (0.788) and MEM (0.454) were observed. Carvacrol content had a significant negative correlation with altitude (-0.632).

\section{Discussion}

\subsection{Essential Oil Content}

According to the current results, there was a significant negative correlation between essential oil content and altitude (Table 4). The findings revealed that the essential oil content of 0 . decumbens was increased by decreasing altitude. Therefore, the highest amounts of essential oils were observed in Khuzestan province populations, where the altitude was lower than others. At higher altitudes, decreased $\mathrm{CO}_{2}$ partial pressure negatively influenced net photosynthetic rate (14), which could influence essential oil content. High altitudes induced UV-B radiation stress, which mainly influences the production of phenolic compounds to absorption and/or dissipation of solar energy (15). Furthermore, these differences in EO may be the result of either uncontrolled biotic and abiotic elicitations or of inherent genetic differences. The current results are in line with the results of previous studies on different medicinal plants $(7,16)$. 


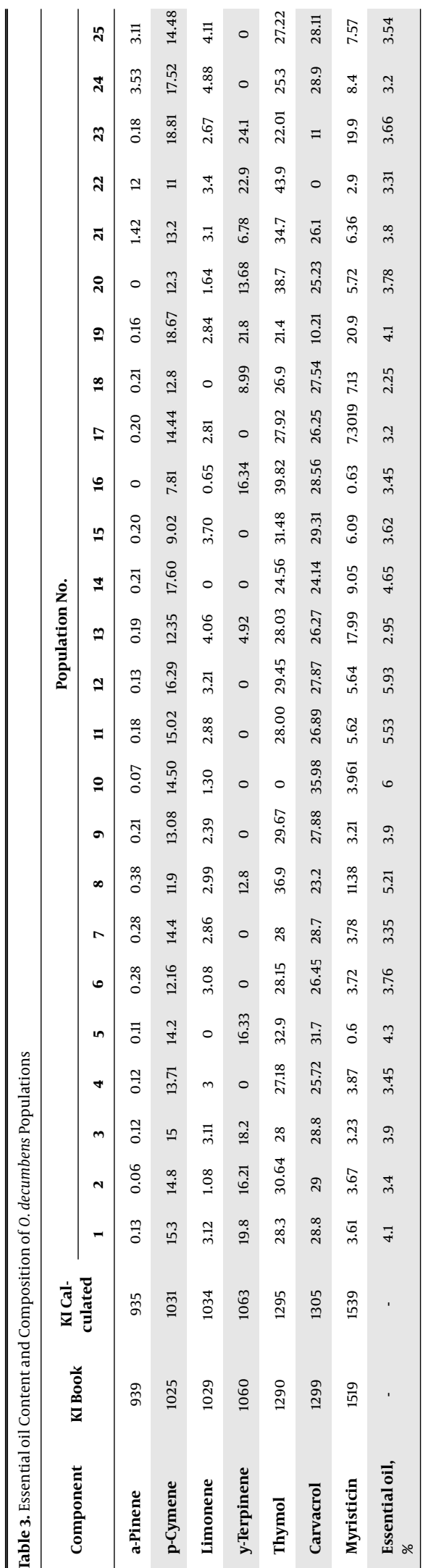

\subsection{Essential Oil Compounds}

In this study, there was a non-significant correlation between some environmental factors and thymol content. The study on Thymus kotschyanus revealed that thymol content was not influenced by changes in altitude (17). Variations in the relative amounts of these compounds under different environmental conditions indicate their adaptively ecological value. According to the current results, it seems that thymol is more stable in different geographical conditions and more affected by genetic factors.

Carvacrol content is positively correlated with MDT and MEM, yet there was a strong negative relationship between carvacrol and location altitude. In this study, content of carvacrol was reduced with increasing altitude. Therefore, differences in the relative quantities of carvacrol in 0 . decumbens populations originated from locations with high MDT, and MEM may be a defense mechanism to extreme temperatures.

Previous studies indicated that meteorological conditions could inhibit or stimulate the synthesis of carvacrol (18-21). The carvacrol content is positively correlated with aridity in Thymus piperella chemotype (18), while a progressive increase of temperature and decrease of humidity was accompanied by a progressive decrease in carvacrol and thymol in T.numidus. Also, temperature differentially influenced percentages of monoterpenic phenols in Origanum vulgare, Origanum majorana, and Origanum syriacum. The increase of temperature was accompanied by an increase of carvacrol, while decrease of temperature was associated with an increase of thymol (20). Similar results were also reported by Vaiciulyte et al. (21) on Thymus pulegioides plants. Homer et al. (22) suggested that a plant's ability to synthesize phytochemicals may be the result of selective pressure and further variability in chemotypes may reflect different selective pressure in different areas.

Previously, the study on Thymus vulgaris chymotypes indicated that carvacrol content increased with decreasing altitude (5). In accordance with the current results, Jamshidi et al. (17) found that carvacrol content of Thymus kotschyanus was reduced by increasing altitude. The relationship between the essential oil components and habitat altitude of Thymus pubescens in East Azarbaijan province revealed that the carvacrol content had a negative correlation with altitude yet it was not significant (7).

In this study, there was a positive correlation between MEM and carvacrol. In a study on chemotype of wild oregano (Origanum vulgare), it was found that they accumulated more essential oil under lower rainfall (23). However, the dry weather increased the essential oils (24). 


\begin{tabular}{|c|c|c|c|c|c|c|c|c|c|}
\hline Variables & MDT, C & MEM, mm & Latitude, $\mathbf{N}$ & Longitude, E & Altitude, m & pH & Clay, \% & Thymol,\% & Carvacrol, \% \\
\hline MEM, mm & $0.634^{\mathrm{a}}$ & & & & & & & & \\
\hline Latitude, $\mathbf{N}$ & -0.115 & $-0.544^{\mathrm{a}}$ & & & & & & & \\
\hline Longitude, E & 0.026 & $0.437^{\mathrm{a}}$ & $-0.972^{\mathrm{a}}$ & & & & & & \\
\hline Altitude, $\mathrm{m}$ & $-0.830^{\mathrm{a}}$ & $-0.449^{\mathrm{a}}$ & -0.265 & 0.355 & & & & & \\
\hline pH & -0.206 & 0.215 & $-0.497^{\mathrm{a}}$ & $0.452^{\mathrm{a}}$ & $0.487^{\mathrm{a}}$ & & & & \\
\hline Clay, \% & -0.121 & $-0.405^{\mathrm{a}}$ & $0.522^{\mathrm{a}}$ & $-0.457^{\mathrm{a}}$ & -0.031 & $-0.547^{\mathrm{a}}$ & & & \\
\hline Thymol,\% & -0.269 & -0.005 & -0.057 & 0.025 & 0.175 & 0.110 & -0.391 & & \\
\hline Carvacrol, \% & $0.788^{\mathrm{a}}$ & $0.454^{\mathrm{a}}$ & -0.079 & -0.033 & $-0.632^{\mathrm{a}}$ & -0.125 & -0.146 & -0.302 & \\
\hline Essential oil,\% & 0.368 & -0.020 & 0.266 & -0.232 & $-0.412^{\mathrm{a}}$ & -0.312 & 0.155 & -0.341 & 0.181 \\
\hline
\end{tabular}

Abbreviations: MDT, mean day temperature; MEM, mean evaporative per month; $\mathrm{pH}$, potential of hydrogen.

${ }^{\text {a }}$ Values are significant $(\alpha<0.05)$.

\subsection{Conclusions}

This study indicated that phytochemical traits of plants are greatly influenced by different climatic conditions. Also, environmental conditions had a significant role on essential oil quantity and quality. The altitude, mean evaporative per month (MEM) and Mean Day Temperature (MDT) were effective macro environmental factors on essential oil, thymol, and carvacrol content. In general, the regions with warm and semi-humid climate were the best locations for essential oil production with high amount of thymol and carvacrol.

\section{Footnotes}

Conflict of Interests: In this study, there were no conflicts with other researchers and institutes.

Funding/Support: In this study, research grants were received from Institute of Medicinal Plants, ACECR. Also, this study was supported by Science and Research Branch, Islamic Azad University in respect to funding.

\section{References}

1. Mahboubi M, Feizabadi MM, Haghi G, Hosseini H. [Antimicrobial activity and chemical composition of essential oil from Oliveria decumbens Vent]. Iran J Med Aromat Plant. 2008;24(1):56-65. Persian.

2. Motamedi H, Darabpour E, Gholipour M, Nejad SMS. Antibacterial effect of ethanolic and methanolic extracts of plantago ovata and oliveria decumbens endemic in Iran against some pathogenic bacteria. Int J Pharmacol. 2010;6(2):117-22. doi:10.3923/ijp.2010.117.122.

3. Bahraminejad S, Seifolahpour B, Amiri R. Antifungal effects of some medicinal and aromatic plant essential oils against Alternaria solani. J Crop Protect. 2016;5(4):603-16. doi:10.18869/modares.jcp.5.4.603.

4. Saidi M. Antioxidant activities and chemical composition of essential oils from Satureja khuzestanica,Oliveria decumbens and Thymus daenensis. J Essent Oil Bearing Plant. 2014;17(3):513-21. doi: 10.1080/0972060x.2014.901607.
5. Torras J, Grau MD, López JF, de las Heras FXC. Analysis of essential oils from chemotypes of Thymus vulgaris in Catalonia. J Sci Food Agricult. 2007;87(12):2327-33. doi:10.1002/jsfa.2995.

6. Delgado T, Marinero P, Asensio-S.-Manzanera MC, Asensio C, Herrero B, Pereira JA, et al. Antioxidant activity of twenty wild Spanish Thymus mastichina L. populations and its relation with their chemical composition. Food Sci Technol. 2014;57(1):412-8. doi: 10.1016/j.lwt.2013.12.041.

7. Dizajeyekan YI, Haghighi AR, Gajoti TE. Regional altitude and soil physicochemical factors influence the essential oil of thymus pubescens (Lamiales: Lamiaceae). J Biol Environ Sci. 2016;10(29):45-51.

8. Karimian V, Vahabi MR, Roustakhiz J, Nodehi N. Identification of some ecological factors affecting essential oil of verbascum songaricum schrenk shoots (Case study: Rangelands of Isfahan and Kohgiluyeh and Buyerahmad provinces, Iran). J Rangeland Sci. 2017;7(2):183-94.

9. Mozafarian V. Flor of Iran (umbelliferae). Forest and Rangelands Research Institute; 2007.

10. Dinauer R. Methods of soil analysis. Madison, Wisconsin (USA): ASA, SSSA; 1982 .

11. Ouariachi EME, Hamdani I, Bouyanzer A, Hammouti B, Majidi L, Costa J, et al. Chemical composition and antioxidant activity of essential oils of Thymus broussonetii Boiss. and Thymus algeriensis Boiss. from Morocco. Asia Pacific JTrop Dis. 2014;4(4):281-6. doi:10.1016/s22221808(14)60573-9.

12. Tohidi B, Rahimmalek M, Arzani A. Essential oil composition, total phenolic, flavonoid contents, and antioxidant activity of Thymus species collected from different regions of Iran. Food Chem. 2017;220:153-61. doi: 10.1016/j.foodchem.2016.09.203. [PubMed: 27855883].

13. Adams RP. Identification of essential oil components by gas chromatography/mass spectrometry. USA: Allured Publishing Corporation Carol Stream IL; 2001.

14. Fujimura S, Shi P, Iwama K, Zhang X, Gopal J, Jitsuyama Y. Effect of altitude on the response of net photosynthetic rate to carbon dioxide increase by spring wheat. Plant Product Sci. 2015;13(2):141-9. doi: 10.1626/pps.13.141.

15. Sampaio BL, Edrada-Ebel R, Da Costa FB. Effect of the environment on the secondary metabolic profile of Tithonia diversifolia: a model for environmental metabolomics of plants. Sci Rep. 2016;6:29265. doi: 10.1038/srep29265. [PubMed: 27383265]. [PubMed Central: PMC4935878].

16. Habibi H, Mazaheri D, Majnoon Hosseini N, Chaeechi MR, FakhrTabatabaee M, Bigdeli M. [Effect of altitude on essential oil and components in wild thyme (thymus kotschyanus boiss) Taleghan region]. Pajouhesh Sazandegi. 2007;73:2-10. Persian. 
17. Jamshidi A, Aminzadeh M, Azarnivand H, Abedi M. [Effect of evaluation for quality and quantity of essential oil Thymus kotschyanus (Damavand - Tar)]. J Med Plant. 2006;2(18):17-22. Persian.

18. Boira $\mathrm{H}$, Blanquer A. Environmental factors affecting chemical variability of essential oils in Thymus piperella L. Biochem System Ecol. 1998;26(8):811-22. doi: 10.1016/s0305-1978(98)00047-7.

19. Hadef Y, Kaloustian J, Chefrour A, Mikail C, Abou L, Giodani R, et al. Chemical composition and variability of the essential oil of Thymus numidicus Poir. from Algeria. Acta Botanica Gallica. 2007;154(2):26574. doi: 10.1080/12538078.2007.10516056.

20. Novak J, Lukas B, Franz C. Temperature influences thymol and carvacrol differentially in Origanum spp. (Lamiaceae). J Essent Oil Res. 2010;22(5):412-5. doi: 10.1080/10412905.2010.9700359.

21. Vaiciulyte V, Butkiene R, Loziene K. Effects of meteorological condi- tions and plant growth stage on the accumulation of carvacrol and its precursors in Thymus pulegioides. Phytochem. 2016;128:20-6. doi: 10.1016/j.phytochem.2016.03.018. [PubMed: 27174744].

22. Homer LE, Leach DN, Lea D, Slade Lee L, Henry RJ, Baverstock PR. Natural variation in the essential oil content of Melaleuca alternifolia Cheel (Myrtaceae). Biochem System Ecol. 2000;28(4):367-82. doi: 10.1016/s0305-1978(99)00071-x.

23. Azizi A, Yan F, Honermeier B. Herbage yield, essential oil content and composition of three oregano (Origanum vulgare L.) populations as affected by soil moisture regimes and nitrogen supply. Indust Crop Prod. 2009;29(2-3):554-61. doi:10.1016/j.indcrop.2008.11.001.

24. Fattahi M, Fattahi B. Principles of medicinal plant. Tehran: Jahat; 2011. Persian. 